\title{
Biochemical profile changes in stored donor blood for transfusion
}

\author{
May AlMoshary', Eman Al Mussaed², \\ Maria Arab-din
}

\begin{abstract}
Objectives: This study's aim was to find out that how various biochemical parameters of donor blood are affected during storage.

Methods: This cross-sectional study was conducted in hematology Unit of Rehman Medical Institute, Peshawar and Fatimid Foundation, Peshawar Khyber Pakhtunkhwa, over a period of six months from June 2018 to November 2018. This study includes 300 healthy volunteer donors. Analysis of stored blood was done at $0,3,7,14-$ and 21-days interval. Data were recorded and analyzed in SPSS $\vee 20$. A p value of less than 0.05 was taken as significant.

Results: Three hundred healthy volunteer donors were included in the study in which $63 \%$ were male and $37 \%$ were females. Mean age was $26.54 \pm 7.3$ years with age range from $23-46$ years. Out of 300 donors 15.33\% were $0+$, 35.33\%, 9.66\% B+, 8.33\% A+, 7.66\% AB+, 7.66\% O-, 7\% A- and 9\% B-. Significant. Changes were observed in serum potassium, $\mathrm{LDH}, \mathrm{pH}$, serum chloride, serum sodium and AST levels. $(\mathrm{p}:<0.001)$. however, storage did not affect rest of the parameters.

Conclusion: This study reveals that during storage certain changes occur in haematological and biochemical parameters which ultimately may put patients at risk.
\end{abstract}

KEYWORDS: Storage lesion, Blood transfusion, Hyperkalaemia.

doi: https://doi.org/10.12669/pjms.35.6.220

How to cite this:

Al-Moshary M, Al-Mussaed E, Arab-din M. Biochemical profile changes in stored donor blood for transfusion. Pak J Med Sci. 2019;35(6):1697-1700. doi: https://doi.org/10.12669/pjms.35.6.220

This is an Open Access article distributed under the terms of the Creative Commons Attribution License (http://creativecommons.org/licenses/by/3.0), which permits unrestricted use, distribution, and reproduction in any medium, provided the original work is properly cited.

\section{INTRODUCTION}

1. Dr. May Al-Moshary, MD.

2. Dr. Eman Al-Mussaed, MD.

3. Dr. Maria Arab-din, MBBS, MPhil (Scholar).

Khyber Medical University,

Peshawar, Pakistan.

1-2: Basic Science department (Hematology), College of medicine, Princess Nourah Bint Abdul Rahman University, Riyadh, Saudi Arabia.

Correspondence:

Dr. Eman Al Mussaed, MD.

Assistant Professor,

Haematology, Basic science department,

Princess Nourah Bint Abdul Rahman University,

Riyadh, Saudi Arabia.

E-mail: dreman_almussaed@hotmail.com

* Received for Publication:

December 18, 2018

* $1^{\text {st }}$ Revision Received:

* $2^{\text {nd }}$ Revision Received:

* Final Revision Received:
February 26, 2019

July 15, 2019

August 5, 2019
Annually almost 11 million units of red cells transfusion occur, making it one of the most common medical intervention. ${ }^{1}$ Ordinarily red cells are administered as a concentrate, known as packed cells with preservative that can be refrigerated for almost 42 days. In order to treat various medical diseases blood transfusion with allogenic blood products is a common medical intervention, ${ }^{2}$ such as anaemia resulting from infection, disorders related to blood synthesis, drugs related cytotoxicity and blood loss in accident, during surgery. ${ }^{3}$ So to improve oxygen delivery to tissue and to lessen the complication of anaemia or related medical procedures transfusion is intended.

All over the world almost 107 million units of whole blood were collected in 2013 of which $67 \%$ 
of blood transfusions in low income countries were administered to children below five years of age where as patients above 65 years constitute relatively $76 \%$ of transfusion in high income countries. ${ }^{4}$

The most common transfused blood component in developed countries are red cells. In contempt of presages that red cells use could increases as population ages with greater use of transfusion in suffering from cancer or cardiac disease, the number of red cell transfusions has decreased from high of approximately 15 million units in 2008 to almost 12 million unit in 2015. Over time red cells transfusion have decreased from 50/1000 population to $40 / 1000 .^{5}$

Appropriate preservation and long-term storage of RBCs is required in order to assure promptly obtainable safe supply for transfusion medicine. RBCs can be stored up to 42 days as per the food and drug administration norms, the storage lesion is a denomination that typically comprises all changes which occurs as RBCs age while in storage solution. These changes lead to haemolysis with concomitant rise in extracellular free iron, haem and haemoglobin that results in nitric oxide diminished bioactivity because of scavenging structural alteration, lactic acid and calcium/ potassium build-up, a decline in 2-3 DPG and ATP, deduction in $\mathrm{PH}$ and glycolysis rate, and an accumulation of shed bioactive proteins, lipids. ${ }^{6-8}$ Serious complications and death in severely ill patients, especially in those patients who are to be operated for any cardiac disease who have received immense transfusion. ${ }^{9}$

Our objective was to find the changes in biochemical parameters in whole blood stored in the blood bank in a resource-limited setting. The findings of this study will provide us with local data for further research.

\section{METHODS}

The present study was conducted in Haematology department, Rehman Medical Institute, Peshawar, Fatimid Foundation, and Peshawar Khyber Pakhtunkhwa from June 2018 to November 2018. From 300 healthy volunteer donors, $450 \mathrm{ml}$ of blood was drawn into citrate phosphate dextrose adenine (CPDA) bags. With due safety precautions blood was collected to avoid contamination and infection. All subjects were serologically tested for hepatitis C, B, and HIV virus. In an isolation shelf in the blood bank at 2-4 $\mathrm{C}^{\circ}$ blood bags were precisely stored. Out of each blood bag a $25 \mathrm{ml}$ of blood was taken for the sake of study and was stowed in plain bags. Analysis of stored blood was done at 0, 3, 7, 14and 28-days interval by withdrawing $5 \mathrm{ml}$ blood each time from the bag. The sample evaluated on day 0 served as control.

By using standard ranges of various parameters used in this study are as follows: urea $(10-50 \mathrm{mg} /$ $\mathrm{d} / \mathrm{L})$, creatinine $(0.7-1.3 \mathrm{mg} / \mathrm{dL})$, ionized calcium (1.1-1.35 mmol/L), AST (upto $40 \mathrm{U} / \mathrm{L}$ ), ALT (upto $40 \mathrm{U} / \mathrm{L})$, total proteins $(6-8 \mathrm{~g} / \mathrm{L})$, LDH $(235-470$ $\mathrm{U} / \mathrm{L})$, sodium $(135-155 \mathrm{mEq} / \mathrm{L})$, potassium (3.5$5.5 \mathrm{mEq} / \mathrm{L})$, chloride $(96-112 \mathrm{mEq} / \mathrm{L})$ and $\mathrm{pH}$ (7.35-7.45). The study was approved by the Ethics Committee of the Rehman Medical Institute, Peshawar Pakistan. (DIR/KMU-EB/CB/000603 dated June 9, 2018)

Statistical Analysis: Standard statistical approaches were used to find the mean and standard deviation. Chi square test was used to find the effect of blood storing on its hematochemical parameters. A $p$ value less than 0.05 was considered as significant. The control used is blood at zero time. All values were quoted as the mean $\pm S D$.

\section{RESULTS}

Out of 300 donors, $189(63 \%)$ were male and $111(37 \%)$ were females. Mean age was $26.54 \pm 7.3$ years with age range from $23-46$ years. Out of 300 donors $46(15.33 \%)$ were $\mathrm{O}+, 106(35.33 \%)$ $29(9.66 \%) \mathrm{B}+, 25(8.33 \%) \mathrm{A}+, 23(7.66 \%) \mathrm{AB}+$, 23(7.66\%) O-, 21(7\%) A- and 27(9\%) B -. Numerous biochemical parameters are shown in Table-I. Noteworthy changes were observed in serum sodium, potassium, chloride, AST, LDH, and $\mathrm{PH}$, $(p<0.001))$. On the other hand, the other parameters were not affected by storage. A steady increase in potassium values were observed.

We also stratified the blood group with the clinical parameters like potassium, chloride, AST, $\mathrm{LDH}$ and $\mathrm{PH}$ and we observed that different blood groups had no effects on clinical parameters and $\mathrm{p}$-value was found insignificant.

\section{DISCUSSION}

Despite advantages of blood transfusion, which is an effective method to avert anemia, preparing patients for surgical interventions and reduce symptoms of blood loss, it may be threatening to recipients. Meanwhile storage of whole blood in 
Biochemical profile changes in stored donor blood

Table-I: Showing biochemical parameters at day $0,3,7,14$ and 28 of storage.

\begin{tabular}{lcccccc}
\hline Parameters & Day 0 & Day 3 & Day 7 & Day 14 & Day 28 & P value \\
\hline Sodium & $152.8 \pm 4.01$ & $150.1 \pm 2.89$ & $147.9 \pm 1.41$ & $143.1 \pm 1.97$ & $141.9 \pm 3.99$ & $<0.001$ \\
Potassium & $4.33 \pm 1.29$ & $6.73 \pm 2.43$ & $9.93 \pm 2.97$ & $14.16 \pm 4.56$ & $19.89 \pm 4.01$ & $<0.001$ \\
Chloride & $86.32 \pm 1.96$ & $89.55 \pm 2.05$ & $93.91 \pm 2.44$ & $96.83 \pm 2.19$ & $91.34 \pm 1.09$ & $<0.001$ \\
Calcium & $0.06+0.007$ & $0.062 \pm 0.005$ & $0.063 \pm 0.004$ & $0.0067 \pm 0.001$ & $0.0066 \pm 0.021$ & NS \\
Urea & $27.71 \pm 3.99$ & $25.19 \pm 2.70$ & $26.11 \pm 3.18$ & $24.32 \pm 2.45$ & $24.17 \pm 2.56$ & NS \\
Creatinine & $0.99 \pm 0.04$ & $1.02 \pm 0.02$ & $1.07 \pm 0.04$ & $1.01 \pm 0.06$ & $1.02 \pm 0.01$ & NS \\
AST $(\mathrm{mg} / \mathrm{dl})$ & $21.95 \pm 4.91$ & $23.54 \pm 6.32$ & $28.43 \pm 3.22$ & $38.26 \pm 9.90$ & $44.31 \pm 8.55$ & $<0.001$ \\
ALT $(\mathrm{mg} / \mathrm{dl})$ & $40.65 \pm 13.65$ & $40.43 \pm 18.89$ & $39.54 \pm 23.66$ & $44.87 \pm 13.76$ & $46.32 \pm 10.87$ & 0.487 \\
LDH $(\mathrm{mg} / \mathrm{dl})$ & $202.54 \pm 17.87$ & $289.21 \pm 23.98$ & $487.91 \pm 97.93$ & $523.65 \pm 113.54$ & $643.32 \pm 187.8$ & $<0.001$ \\
Proteins $(\mathrm{g} / \mathrm{dl})$ & $6.76 \pm 0.77$ & $6.43 \pm 0.76$ & $5.99 \pm 0.11$ & $6.87 \pm 0.3$ & $6.7 \pm 0.88$ & NS \\
PH & $7.22 \pm 0.18$ & $7.01 \pm 0.33$ & $6.91 \pm 0.44$ & $6.89 \pm 0.23$ & $6.77 \pm 0.54$ & $<0.001$ \\
\hline
\end{tabular}

the blood bank, various alteration was noticed. A few parameters showed elevated where as some revealed reduced values.

Results of this study demonstrate many potential noxious changes that occur in the blood during storage. An exchange of content between plasma and red cells occurs because of prolong contact of plasma with RBCs that leads to changes in analyte concentrations as well as dilution. Potassium levels marked up within three days and this increase persist subsequently. from day 1 to day 28 of storage there was a notable ascent in $\mathrm{K}$ concentration $(<0.001)$, almost $1 \mathrm{mEq} / \mathrm{L}$ of the extracellular $\mathrm{K}$ level increase daily in stored blood, which revealed that there is higher concentration during the early days of storage. ${ }^{10}$

One of the study from Ghana demonstrated that there is increase in concentration of potassium on day $10^{\text {th }}$ and $15^{\text {th }}$ by $21.4 \%$ and $60.7 \%$ respectively. ${ }^{11}$ An upsurge in ECF potassium concentration decreases in ECF sodium concentration and will result in collateral opposite effect in ICF where NA and $\mathrm{K}+$ concentrating changes as well because of failure of Na-K pump. Wallas first hypothesized the failure of Na-K ATPase action during the storage period, under normal condition $\mathrm{Na}-\mathrm{K}$ pumps 3 $\mathrm{Na}+$ ions out of the cells for $2 \mathrm{~K}+$ ions pumped in. ${ }^{12}$ suppression of pump cause hyponatremia and hyperkalaemia as to be found in the present study. A similar study by Jobes et al. ${ }^{13}$ showed the same finding regarding sodium as in this study, where declining level of sodium were reported during the storage of blood.
Initially up to seven days chloride level accelerated after which a notable decline was observed. Sodium, calcium, and chloride are low molecular compounds and by storing, these enter into RBC's under the effect of their concentration gradients. ${ }^{14}$

In AST level considerable change $(\mathrm{p}<0.001)$ were noticed which could be due to haemolysis as observed by other authors. Koseoglu et al. study showed that haemolysis interference affected LDH and AST almost at untraceable haemolysis by visual inspection (plasma haemoglobin $<0.5 \mathrm{~g} / \mathrm{L}$ ) while clinically expressive differences of potassium and total bilirubin were observed in moderately haemolysed samples (haemoglobin $>1 \mathrm{~g} / \mathrm{L}$ ). ALT, cholesterol, gamma-glutamyltransferase (GGT), and inorganic phosphate concentrations were not interfered up to severely haemolysed levels (haemoglobin: $2.5-4.5 \mathrm{~g} / \mathrm{L}){ }^{15}$

In the present study it was also found that $\mathrm{PH}$ of stored blood decline during storage, also the drop in $\mathrm{PH}$ elevated with increase in storage time. $(p=0.001)$. The drop in the PH would be due to upsurge in the level of lactate because of anaerobic metabolism of glucose and besides the drop in $\mathrm{PH}$ was directly proportional to the surge in lactate level. ${ }^{16}$ On 0 -day $\mathrm{pH}$ was within normal range which fell to 6.77 at the end of 28 th day. For every 0.1 unit of $\mathrm{pH}$ alteration results in a $0.4 \mathrm{mmol} / \mathrm{L}$ alteration in the serum potassium level. Acidosis cause rise in Potassium levels while alkalosis reduced the potassium level. ${ }^{17}$ It has been shown that a decline in $\mathrm{pH}$ and levels of 
lactate and potassium start rising within a couple of hours of storage while other changes may take weeks to appear. ${ }^{8}$

\section{CONCLUSION}

This study showed that variations to several hematological and biochemical parameters occur during the storage of blood, despite storing blood in CPDA bag, and subsequently may cause untoward risks to patients. It is better to give patients fresh blood which has been stored for less than seven days.

\section{Grant Support E Financial Disclosures: None.}

\section{REFERENCES}

1. Carson JL, Stanworth SJ, Roubinian N, Fergusson DA, Triulzi D, Doree C, et al. Transfusion thresholds and other strategies for guiding allogeneic red blood cell transfusion. Cochrane Database Syst Rev. 2016;10:Cd002042. doi: 10.1002/14651858.CD002042.pub4

2. Carson JL, Triulzi DJ, Ness PM. Indications for and Adverse Effects of Red-Cell Transfusion. N Engl J Med. 2017;377(13):1261-1272. doi: 10.1056/NEJMra1612789

3. Garcia-Roa M, Del Carmen Vicente-Ayuso $M$, Bobes AM, Pedraza AC, Gonzalez-Fernandez A, Martin $\mathrm{MP}$, et al. Red blood cell storage time and transfusion: current practice, concerns and future perspectives. Blood Transfus. 2017;15(3):222-231. doi: 10.2450/2017.0345-16

4. Organization $\mathrm{WH}$. The 2016 global status report on blood safety and availability. 2017.

5. Aboudara MC, Hurst FP, Abbott KC, Perkins RM. Hyperkalemia after packed red blood cell transfusion in trauma patients. J Trauma. 2008;64(2):S86-S91. doi: 10.1097/TA.0b013e318160c0b8

6. Antonelou MH, Kriebardis AG, Papassideri IS. Aging and death signalling in mature red cells: from basic science to transfusion practice. Blood Transfus. 2010;8(Suppl 3):s39-s47. doi: 10.2450/2010.007S

7. Takei T, Amin NA, Schmid G, Dhingra-Kumar N, Rugg D. Progress in global blood safety for HIV. J Acquir Immune Defici Syndr. 2009;52(Suppl 2):S127-S131. doi: 10.1097/QAI.0b013e3181baf0ac
8. D'Alessandro A, D'Amici GM, Vaglio S, Zolla L. Time-course investigation of SAGM-stored leukocyte-filtered red bood cell concentrates: from metabolism to proteomics. Haematol. 2012;97(1):107-115. doi:10.3324/haematol.2011.051789

9. Hardy JF, Moerloose PD, Samama CM. Transfusion massive et coagulopathie-: physiopathologie et implications cliniques. Canad J Anesth. 2006;53(2):S40. doi: 10.1007/ BF03022251

10. Zimrin $\mathrm{AB}$, Hess JR. Current issues relating to the transfusion of stored red blood cells. Vox Sanguinis. 2009;96(2):93-103. doi: 10.1111/j.1423-0410.2008.01117.x

11. Opoku-Okrah C, Acquah BKS, Dogbe EE. Changes in potassium and sodium concentrations in stored blood. Pan Afr Med J. 2015;20:236. doi: 10.11604/pamj.2015.20.236.5851

12. Wallas $\mathrm{CH}$. Sodium and potassium changes in blood bank stored human erythrocytes. Transfusion. 1979;19(2):210-215. doi: 10.1046/j.1537-2995.1979.19279160297.x

13. Jobes D, Wolfe Y, O'Neill D, Calder J, Jones L, SesokPizzini D, et al. Toward a definition of "fresh" whole blood: an in vitro characterization of coagulation properties in refrigerated whole blood for transfusion. Transfusion. 2011;51(1):43-51. doi: 10.1111/j.1537-2995.2010.02772.x

14. Heins M, Heil W, Withold W. Storage of serum or whole blood samples? Effects of time and temperature on 22 serum analytes. Eur J Clin Chem Clin Biochem. 1995;33(4):231-238.

15. Koseoglu M, Hur A, Atay A, Cuhadar S. Effects of hemolysis interferences on routine biochemistry parameters. Biochem Med. 2011;21(1):79-85. doi: 10.11613/BM.2011.015

16. Hillyer C, Tiegerman K, Berkman E. Evaluation of the red cell storage lesion after irradiation in filtered packed red cell units. Transfusion. 1991;31(6):497-499. doi: 10.1046/j.15372995.1991.31691306244.x

17. Hess JR, Sparrow RL, van der Meer PF, Acker JP, Cardigan RA, Devine DV. Red blood cell hemolysis during blood bank storage: using national quality management data to answer basic scientific questions. Transfusion. 2009;49(12):25992603. doi: $10.1111 / j .1537-2995.2009 .02275 . x$

\section{Authors' Contribution:}

MAM, EAM: Conceived, designed and did statistical analysis \& editing of manuscript.

MA: Did data collection and manuscript writing. MA, MAM, EAM: Did review and final approval of manuscript. 